\title{
DEMOCRACY AND SECULARISM: REMARKS ON AN ONGOING DISPUTE
}

\author{
DEMOCRACIA E SECULARISMO: OBSERVAÇÕES SOBRE UMA \\ DISPUTA EM ANDAMENTO
}

\author{
LUIZ BERNARDO L. ARAUJO ${ }^{1}$ \\ (UERJ/Brazil)
}

\begin{abstract}
This paper focus on the disputed issue concerning the proper role of religion in politics, confronting the contributions of three major contemporary political thinkers about democracy and secularism. I present, first, Charles Taylor's characterization of secularist regimes as attempts to secure the basic principles of the modern moral order. Next, I argue that John Rawls's growing interest in the relation between religion and democracy led him to an even more inclusive view of public reason. Thirdly, I show that Jürgen Habermas preserves a distinction between faith and knowledge that proves essential to grasping the debate over the place of religion in the public sphere. All three thinkers are concerned with the appropriate forum for the basic political language of the secular state. In a nutshell, my interpretation highlights a much greater proximity between Habermas and Rawls on political justification, on the one hand, and between the former and Taylor regarding the normative basis for the secular state, on the other hand, than their various interventions seem to indicate.

Keywords: Rawls. Habermas. Religion. Secularism. Democracy.
\end{abstract}

One of the most disputed issues in recent years is the proper role of religion in democratic politics. Usually, the various positions taken on the debate are classified according to a binary code representing ideal-types perspectives: exclusive and inclusive ${ }^{2}$. What is troubling about this classification is the fact that no one holds a pure exclusivist or separatist view and, perhaps with the sole exception of Nicholas Wolterstorff ${ }^{3}$, all political philosophers endorse one version or another of the so-called standard approach exemplified by the work of John Rawls. According to the standard approach, as presented by Paul Weithman (WEITHMAN, 2002, p.6-9) and summarized by James Boettcher and Jonathan Harmon ${ }^{4}$, "respect for the freedom and equality of fellow citizens implies that basic or coercive political arrangements should be justifiable to them by the right sorts of reasons", or by a suitable political justification "which addresses a diverse group of citizens and which satisfies some proposed condition or criterion". In this sense, targeting primarily the problem of political legitimacy, concerning "how coercive laws and policies may be politically justified in light of a philosophically defensible normative standard", the discussion also revolves around the quest for an ethics of citizenship, concerning "which obligations or excellences should be 
associated with persons in virtue of their roles as liberal-democratic citizens and officials", thus requiring citizens not only to pursue a non-sectarian justification "but also, at times, to exercise restraint in their political appeal to religious doctrine". My claim is that Charles Taylor does not pay sufficient attention to the inclusive, albeit weak, dimensions of John Rawls's approach over the issue of religion and democracy. Once removed a possible ambiguity in the Rawlsian idea of public reason, I think that the controversy is strongly determined by Jürgen Habermas's post-secular paradigm, which proposes a new implementation of the translation proviso but opposes the deflation of the distinction between religious and secular reasons.

"We are condemned to live in an overlapping consensus". This statement is not of John Rawls, as one would expect, but of Charles Taylor, one of his most incisive and

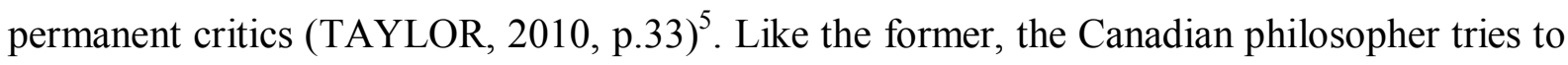
identify acceptable forms of coexistence and integration among citizens of liberal democracies characterized by a plurality of worldviews and conceptions of the good. Since the "modern moral order" is founded on the basic principles of the rights and liberties of its members (human rights), the equality among them (nondiscrimination) and the principle that rule is based on consent (democracy), it cannot but be organized around a "philosophy of civility" that emerged from the crumbling edifice of the cosmic-religious outlooks, giving rise to a new conception of the political in which the idea of "secularism" or "laïcité" has become an essential component. In modern democratic societies, social cohesion depends on an ethics of citizenship supported by communities whose reasons differ one from another, requiring a political justice equidistant from the different positions and a public language free of assumptions drawn from one or another form of belief and also - it is important - of disbelief.

So, for Taylor, a broad consensus was established on the secular (or laïque) feature of any liberal democracy. But a secular regime, whose main purposes are respecting the moral equality of individuals, on the one hand, and protecting their freedom of conscience, on the other, should be understood in the larger context of the diversity of beliefs and values religious or nonreligious - of the citizens. In his opinion, the so-called "secularism" refers to the response of the democratic state to widespread diversity, and not exactly to the relationship between religion and political institutions. Taylor's notion of secularity "stands not only in contrast with a divine foundation for society, but with any idea of society as constituted in something which transcends contemporary common action" (TAYLOR, 2007, p.192.), and that's the reason for his agreement with the late-Rawlsian formulation of an 
"overlapping consensus" between incompatible comprehensive doctrines on a "common philosophy of civility". As he says, "the point of state neutrality is precisely to avoid favoring or disfavoring not just religious positions, but any basic position, religious or nonreligious. We can't favor Christianity over Islam, nor can we favor religion over nonbelief in religion, or vice versa" (TAYLOR, 2011a, p.311).

However, considering Taylor's insistence on the self-sufficiency of reason as a distinctive feature shared by two of our major contemporary political thinkers, Rawls and Habermas, some disputed issues remain in this controversy whose origin seems to be in the very polysemy of the term "secular". From Taylor's standpoint, the complexity of this term disappears in the master narratives of secularization. Their "subtraction stories" make a "special case" of religion, defining secularism in terms of specific institutional arrangements, whose "fetishization" obliterates the fact that they are derived from the need to balance the goods - not always easily combinable - of the modern moral order, and invoking the "Wall of separation" or the "laïcité" - based on the radical opposition between the religious and the secular - as the ultimate criterion of modern secularity ${ }^{7}$. In this way, both philosophers, Rawls and Habermas, adopt one of the forms taken by the "myth of the Enlightenment", that is, the distinction in rational credibility between religious and nonreligious discourse, and hence remaining stuck in the old rut of a "fixation on religion" as the problem of political life in democratic societies.

In regard to Rawls, it seems to me very important to notice that the growing interest on the relation between religion and democracy led his political liberalism to an even more inclusive view of the public reason. In fact, in the Introduction to the Paperback Edition of Political Liberalism, the American philosopher identifies in the particular attention to the nonliberal comprehensive doctrines the fundamental problem of the work, presenting the philosophical question it primarily addresses in the following way: "How is it possible for those affirming a religious doctrine that is based on religious authority, for example, the Church or the Bible, also to hold a reasonable political conception that supports a just democratic regime?" (RAWLS, 2005, p.xxxvii) ${ }^{8}$. Then he fosters a new revision of the idea of public reason exposed in the sixth lecture of the book, and refers for the first time to the proviso, specifying what he calls the "wide view" of public reason and adopting an even more permissive position concerning the introduction of comprehensive reasons in the public political forum. As Rawls puts it, "reasonable comprehensive doctrines, religious or nonreligious, may be introduced in public political discussion at any time, provided that in 
due course proper political reasons - and not reasons given solely by comprehensive doctrines - are presented that are sufficient to support whatever the comprehensive doctrines introduced are said to support" (RAWLS, 2005, p. 462) ${ }^{9}$.

What am I trying to point out here? Briefly, my point is that, contrary to what Taylor assumes, Rawls rejects the identification of "public reason" and "secular reason", insofar as the latter is defined "as reasoning in terms of comprehensive non religious doctrines", whose values "are much too broad to serve the purposes of public reason" (RAWLS, 2005, p. 452). Philosophical and moral doctrines are on a level with religion and are subject to the same restrictions imposed by the "criterion of reciprocity". Therefore, Rawls emphatically denies that his arguments constitute a veiled form of secularism, considering - not without irony that they could be regarded as a veiled form of religiosity. In his vision, there are two kinds of comprehensive doctrines, religious and secular, and the political arguments in terms of public reason are the common ground on which people can understand each other and cooperate ${ }^{10}$. Rawls's central distinction is not between secular and religious reasons, but rather between public and nonpublic reason, the former applying only to fundamental political questions, namely, constitutional essentials and matters of basic justice.

The controversy lies more in the place and the application of the language shared by the members of a political community than in the religious or secular character of public reason. Taylor himself admits that "there are zones of a secular state in which the language used has to be neutral", acknowledging that "the lines are hard to draw, and they must be drawn anew. But such is the nature of the enterprise that is the modern secular state. And what better alternative is there for diverse democracies?" (TAYLOR, 2011a, p.320-21). In this sense, I think that, once removed from the Rawlsian idea of public reason a possible lack of clarity to discriminate between political discussion and political decision-making ${ }^{11}$, the debate turns around the distinction between faith and knowledge preserved by Habermas, as well as around the appropriate forum for the basic political language of the secular state, an idea entertained to some extent by the three thinkers ${ }^{12}$.

Against Rawls, as is well known, Habermas argues that the so-called overlapping consensus is possible only with the adoption of a "moral point of view" independent of, and prior to, the comprehensive doctrines, which counts as a normative criterion for a nonarbitrary identification of the reasonableness of metaphysical and religious worldviews (Cf. HABERMAS, 1999, p. 86-94). Habermas's main criticism of political liberalism, based on his rejection of Rawls's strategy of avoidance in regard of the notion of truth, addresses a 
consensus resulting from a "felicitous overlapping" of comprehensive doctrines and the "lucky convergence" of reasonable worldviews (HABERMAS, 1999, p. 78 and 83). Nevertheless, Rawls's position, in my opinion, is more complex and subtler than it appears at first sight. The Rawlsian idea of public reason, at least in the last phase of its development, indicates that the so-called overlapping consensus is not a casual result of convergence between conflicting comprehensive doctrines. On the contrary, since it is bound to an ideal of justification whose central aspect resides in the public reasoning of citizens, it may only play an appropriate role in political justification when it contributes to the social stability by means of right reasons. Instead of being interpreted as a mere accommodation of diverging worldviews, Rawls's conception of political justice must be analyzed on the light of the notion of rational acceptability grounded on the liberal principle of legitimacy (Cf. ARAUJO, 2007).

Probably, however, Habermas's notion of acceptability is stronger than the Rawlsian one. As Finlayson and Freyenhagen state in the Introduction to a new book dedicated to the dispute between Habermas and Rawls, “while Rawls's strategy of avoidance is arguably his downfall, Habermas by contrast might be said to take too many (philosophical) hostages to fortune" (FINLAYSON and FREYENHAGEN, 2010, p.19). In any case, the German philosopher reaffirms, in his recent review article on Rawls's posthumous publication on religion, that "it ultimately remains indeterminate which of the two authorities should have the final word in the justification of the political concept of justice - faith or knowledge" (HABERMAS, 2010, p.452). Taylor is therefore correct when he says that Habermas "has always marked an epistemic break between secular reason and religious thought", even though "his position on religious discourse has considerably evolved" (TAYLOR, 2011b, p.49-50).

Such a change in Habermas's perspective, dated roughly around the turn of the millennium, can be credited to his appropriation of Rawls's idea of the public use of reason. Thus Habermas calls Rawls "the first among the major political philosophers to take religious and metaphysical pluralism seriously and to launch a fruitful debate concerning the status of religion in the public sphere" (HABERMAS, 2010, p.452). Habermas's intention is to avoid the confusion between arguments incompatible with the secular character of the state and well-founded objections to a secularist understanding of democracy and the rule of law. For this reason he tries to meet both the empirical and the normative objections to the Rawlsian proviso - objections to the feasibility and the fairness of Rawls's approach to the question of 
public reason and religion - with a different kind of implementing its requirement of translation (Cf. HABERMAS, 2011, p. 25-27).

Understanding Habermas in this way may clarify his relation with Taylor. The main point of disagreement between Taylor and Habermas is not the need for an "institutional translation", but the importance of the difference over types of reasons for political discourse, as well as the delimitation of the spaces in which the language of the state should be neutral. Taylor believes that their disagreement lies more in their rationales than in the practice they recommend. Thus he concludes that they "both recognize contexts in which the language of the state has to respect a reserve of neutrality and others in which freedom of speech is unlimited" (TAYLOR, 2011b, p. 58, note 12). Habermas, in contrast, thinks that behind the strategy of deflating the distinction between religious and secular reasons there is a defensive reaction of those who call for a deeper grounding of the basic principles of the modern moral order. In this way, the politics of secularism renews the discussion about the concept of the political as (supposedly) located beyond its pure self-immanence, or about the coherence (whether or not) of the basic political ideals of modern democratic societies when divorced from their religious origins. I will not pursue this point here. Let me just remind that we don't need to revive political theology to be sure that "in the course of its democratic transformation, 'the political' has not completely lost its association with religion" (HABERMAS, 2011, p. 27) ${ }^{13}$. 


\begin{abstract}
Notes:
${ }^{1}$ Luiz Bernardo Leite Araujo is Associate Professor of Ethics and Political Philosophy at the State University of Rio de Janeiro, (Rio de Janeiro, Brazil), and Researcher of the Brazilian Research Council (CNPq). He is the author of Religião e Modernidade em Habermas (Loyola, 1996) and Pluralismo e Justiça: Estudos sobre Habermas (Loyola 2010), and has published several articles and chapters on deliberative democracy, religion and politics, and public reason. E-mail: lbaraujo@uerj.br
\end{abstract}

${ }^{2}$ For an attempt to compile some of the most significant contributions to the debate concerning whether citizens should allow their religious convictions to filter into their lives within the political domain: (CLANTON, 2009). Representatives of the separatist and integrationist views, another way of classifying the two broad categories, are Bruce Ackerman, Robert Audi, Stephen Macedo, Thomas Nagel, and Richard Rorty, on the one hand, and Christopher Eberle, Paul Weithman, Michael Sandel, Jeffrey Stout, and Nicholas Wolterstorff, on the other.

${ }^{3}$ See his contributions in (AUDI and WOLTERSTORFF, 1996).

${ }^{4}$ The following quotations come from their helpful introduction to a special issue on religion and the public sphere: (BOETTCHER and HARMON, 2009).

${ }^{5}$ The sentence reappears in at least two other texts, although inexplicably without the preposition ("We are condemned to live an overlapping consensus"). (TAYLOR, 2011a, p.319); (TAYLOR, 2011b, p.48). In what follows, see (ARAUJO, 2011a).

${ }^{6}$ On this notion, see Lecture IV (The Idea of an Overlapping Consensus) in: (RAWLS, 2005, p.133-172).

${ }^{7}$ It is worth noting that the "Wall of separation" and the "laïcité" correspond to two historical models of what constitutes a secular regime, linked to the founding contexts of the American and the French Revolutions. These two forms of the dominant self-understanding of western secularism interpret the separation of religion and state as "exclusion" - mutual or one-sided, respectively -, as shown by Rajeev Bhargava, whose conception of secularism based on the idea of "principled distance" is endorsed by Taylor. And for him, Mark Lilla's The stillborn God is a representative book of the mainstream conceptions of western secularism.

${ }^{8}$ On the inclusive view of Rawls's idea of public reason, cf. (ARAUJO, 2011b).

${ }^{9}$ This quotation comes from his last article, published in 1997 and included in the expanded edition of Political Liberalism. According to Rawls, "the Chicago article is by far the best statement I have written on ideas of public reason and political liberalism", especially regarding their relation "to the major religions that are based on the authority of the church and sacred text, and therefore are not themselves liberal" (RAWLS, 2005, p. 438).

${ }^{10}$ Cf. RAWLS, 1999: 619-20. The "Commonweal Interview with John Rawls", incorporated in his Collected Papers (pp. 616-22), took place in January 1998.

${ }^{11}$ Larmore (2003) observes that "neither in Political Liberalism nor in The Idea of Public Reason Revisited does he note the difference between two forms of public debate - open discussion, where people argue with one another in the light of the whole truth as they see it, and decision making, where they deliberate as participants in some organ of government about which option should be made legally binding” (p. 382).

${ }^{12}$ In a recent article, Menny Mautner (2013) comes somewhat close to my claim when he notices Rawls's failure to distinguish between "deliberation" and "justification", arguing that Habermas's position on public reason is superior to that of Rawls in that it is premised on a clear distinction between deliberation and justification, even though some of Habermas's critiques of Rawls are unjustified. I agree with this, but I don't see any contradiction in the German philosopher's position, since in my opinion Habermas's concern when he talks about the asymmetrical burden imposed on religious citizens is relevant not only to religious fundamentalists, but also to non-fundamentalist religious believers. 
${ }^{13}$ Both Habermas and Taylor allude to the important distinction between le politique and la politique proposed by Claude Lefort in his famous article "Permanence du théologico-politique?", originally published in 1981 (Le Temps de la Réflexion, n. 2, pp. 13-60). 


\section{References:}

ARAUJO, L. B. L. "A decade of debate: discourse theory versus political liberalism". Archiv fur Rechts- und Sozialphilosophie - Beihefte (ARSP-B), Band 107 (2007): 87-96.

vol. 10 (2011a): 39-53.

"A ordem moral moderna e a política do secularismo". Ethic@ (UFSC),

"John Rawls e a visão inclusiva da razão pública". Dissertatio (UFPel), vol. 34 (2011b): 91-105.

AUDI, R. and WOLTERSTORFF, N. Religion in the public square: the place of religious convictions in political debate. Lanham: Rowman \& Littlefield Publishers, 1996.

BHARGAVA, R. "What is secularism for?", in Rajeev Bhargava (ed.). Secularism and its critics. New Delhi: Oxford University Press, new edition, 2005, pp. 486-542.

BOETTCHER, J. W. and HARMON, J. "Introduction: religion and the public sphere". Philosophy and Social Criticism, vol. 35 (2009): 5-22.

CLANTON, J. (ed.). The ethics of citizenship: liberal democracy and religious convictions. Waco (Texas): Baylor University Press, 2009.

FINLAYSON, J. G. and FREYENHAGEN, F. (eds.). Habermas and Rawls: disputing the political. London: Routledge, 2010.

HABERMAS, J. “'Reasonable' versus 'true', or the morality of worldviews", in The inclusion of the other. Cambridge [Mass.]: MIT Press, 1999, pp. 75-101.

. Between naturalism and religion. Cambridge: Polity Press, 2008.

"'The 'good life' - a 'detestable phrase': the significance of the young Rawls's religious ethics for his political theory”. European Journal of Philosophy, vol. 18 (2010): 443-54.

. "The political: the rational meaning of a questionable inheritance of political theology", in Eduardo Mendieta and Jonathan VanAntwerpen (eds.). The power of religion in the public sphere. New York: Columbia University Press, 2011, pp. 15-33.

LARMORE, C. "Public reason", in Samuel Freeman (ed.). The Cambridge Companion to Rawls. Cambridge: Cambridge University Press, 2003, pp. 368-93.

LILLA, M. The stillborn God: religion, politics, and the modern West. New York: Knopf, 2007.

MAUTNER, M. "Religion in politics: Rawls and Habermas on deliberation and justification". Tel Aviv University Law Faculty Papers, Working Paper 167 (2013): 1-39. 
RAWLS, J. "The idea of public reason revisited". The University of Chicago Law Review, vol. 64 (1997): 765-807.

. Collected Papers. Cambridge [Mass.]: Harvard University Press, 1999.

. Political liberalism: expanded edition. New York: Columbia University Press, 2005 (first edition: 1993).

. A brief inquiry into the meaning of sin and faith: with "On My Religion" (edited by Thomas Nagel). Cambridge [Mass.]: Harvard University Press, 2010.

TAYLOR, C. A secular age. Cambridge [Mass.]: Harvard University Press, 2007.

. "The meaning of secularism". The Hedgehog Review, vol. 12 (2010): 23-34.

. "What does secularism mean?", in Dilemmas and connections. Cambridge [Mass.]: Harvard University Press, 2011a, pp. 303-325.

. "Why we need a radical redefinition of secularism", in Eduardo Mendieta and Jonathan VanAntwerpen (eds.). The power of religion in the public sphere. New York: Columbia University Press, 2011b, pp. 34-59.

WEITHMAN, P. Religion and the obligations of citizenship. Cambridge: Cambridge University Press, 2002. 